\title{
First report of infection by Debaryomyces spp. in Myotis velifer (cave myotis) in Mexico
}

\author{
Héctor Tamayo ${ }^{1,2}$, Miguel A. Domínguez ${ }^{2}$, Luz María Ramírez Acevedo ${ }^{3}$, \\ Graciela E. González Pérez ${ }^{1}$, Margarita García-Luis ${ }^{1,2}$, Diego Pérez de la Rosa ${ }^{4}$, \\ Miguel Briones-Salas ${ }^{1}$
'Instituto Politécnico Nacional (IPN), CIIDIR Unidad Oaxaca, Laboratorio de Vertebrados Terrestres, Municipio de Santa Cruz Xoxocotlán, Oaxaca, México
${ }^{2}$ Universidad Autónoma Benito Juárez de Oaxaca, Facultad de Medicina Veterinaria y Zootecnia, Laboratorio de Genética Molecular y Zoonosis, Oaxaca, México
${ }^{3}$ Laboratorio Clínico Veterinario Especialista en Patología Clínica "DxVet", Oaxaca, México
${ }^{4}$ Centro Nacional de Servicios de Constatación en Salud Animal, Jiutepec, Morelos, México

Received January 23, 2021

Accepted August 31, 2021

\begin{abstract}
Interest in the study of mycotic diseases in bats has increased after the identification of bats affected by white-nose syndrome in the northern United States. In a temperate forest of the community of San Pedro Yolox, Ixtlán in the Sierra Madre de Oaxaca, Mexico, we collected bats of various species, including 13 specimens of Myotis velifer that showed lesions in the plagio- and uro-patagium. Clinical exploration, histopathological studies and molecular analysis were carried out to determine the causal agent of the lesions present in these individuals. It was determined that the cause was the pathogenic fungus Debaryomyces spp. The present study represents the first report of fungal infection in bats in southern Mexico.
\end{abstract}

Bats, dermatomycosis, diseases, mammals, mycosis, pathogens

The fungal agent Pseudogymnoascus destructans responsible for bat population declines in the northern United States has increased the interest in the study of bat fungal diseases. White-nose syndrome (WNS) is associated with the growth of $P$. destructans hyphae on the ears, nose, metatarsals, and other furless skin areas of body in insectivorous bat species during the period of hibernation. Therefore, P. destructans causes destruction of the apocrine and sebaceous glands, hair follicles and other dermal tissues (Cryan et al. 2010). While the wings play a fundamental role in gas exchange (contributing up to $10 \%$ of the total), wing membrane damage caused by WNS impacts the gas exchange, mobility and hydration status of infected bats. In addition to the fungus $P$. destructans, other pathogenic fungi have been discovered, such as Trichophyton redellii and Debaryomyces spp., responsible for similar but less common skin diseases (Blehert et al. 2009).

Trichophyton redellii is characterized by the development of lesions similar to WNS, with the difference that it does not fluoresce under a UV lamp and that the characteristic growth of fungal structures is in the snout, while Debaryomyces spp. was reported in a case with lesions similar to those of WNS but without describing the status of the infected specimen in greater detail (Lorch et al. 2015). Mexico is notable for the presence of 139 bat species distributed throughout its territory (Ramírez-Pulido et al. 2014). However, there is no published report on a fungal dermatological monitoring of this group of mammals.

During our study on the ecological aspects of a community of bats in the Sierra Norte de Oaxaca, we collected some individuals of Myotis velifer with damaged wings. For this reason, we decided to investigate the causal agent of the lesions present in these individuals. 


\section{Materials and Methods}

In February 2017, in the temperate forest located in the community of San Pedro Yolox, Ixtlán, in the Sierra Madre de Oaxaca, Mexico, a bat of the species $M$. velifer was collected. The specimen was subjected to the Wood lamp test, a battery-operated lamp from the LUX pro brand was used with 32 UV LEDs with a wavelength of 385-390 nm. The signology similar to WNS was the presence of "spots" in the patagium and uropatagium as well as the presence of fungal structures on histology (Turner et al. 2014). It was decided to euthanize the specimen using isoflurane overdose as described by Barnard (2009). Two tissue samples were collected from the plagiopatagium $\left(1 \mathrm{~cm}^{2}\right)$, one placed in $10 \%$ formaldehyde and the other stored at $-20^{\circ} \mathrm{C}$ for molecular analysis. The wing membrane was stained with haematoxylin and eosin.

Genomic DNA was isolated from the collected tissue using the commercial kit DNeasy Blood \& Tissue (Qiagen, Bodenseeallee, Stockach, Germany) following the manufacturer's instructions. The fungal ITS region was amplified with the primers ITS5 (5'-GGAAGTAAAAGTCGTAACAAGG-3') and 5.8S_fungi (5'-CAAGAGATCCGTTGTTGAAAGTT-3'; Young et al. 2014), and sequenced using the 454 pyrosequencer (454 LifeScience, Roche Diagnostics, Branford, Pennsylvania, USA). The contigs obtained were assembled using the Bioinformatics software Newbler version 2.5.3 (Roche Diagnostic) and Consed version 23 (http://www.phrap. $\mathrm{org} / \mathrm{consed} /$ consed.html). The sequences were arranged according to the number of readings obtained (Table 1) and compared with the information contained in the NCBI database through the BLAST tool (https://blast.ncbi. nlm.nih.gov/).

Subsequently, 12 individuals of $M$. velifer with similar patterns of wing lesions were captured and a clinical review was carried out. For the review, two $1 \mathrm{~cm}^{2}$ samples of plagiopatagium were obtained from each bat with a scalpel for histopathological and molecular studies. In addition, an inspection of the wings was carried out according to the wing damage index proposed by Reichard and Kunz (2009). The specimens were captured with the permission of the Government of Mexico through La Secretaría del Medio Ambiente y Recursos Naturales (SEMARNAT), number FAUT-0037.

To confirm the presence of Debaryomyces spp., a pair of specific primers was designed (DEB-18S-FW: 5'-CAAGAACTTTTGCTTTGGTCT-3' and DEB-18S-RW: 5'-GCACTATCCAGTACCACTCAT-3') to amplify a 384-bp fragment from the ITS region of Debaryomyces spp. The fragment amplification reaction was carried out using the Accuzyme DNA polymerase kit (Bioline, Humber Road, London, UK) following the manufacturer's instructions. The reaction mixture included $1 \mu \mathrm{l}$ of extracted genomic DNA $(50 \mathrm{ng} / \mu \mathrm{l}), 1 \mu \mathrm{l}(10 \mu \mathrm{Mol})$ of each primer (DEB-18S-FW and DEB-18S-RW), $5 \mu$ l Accuzyme reaction mixture (1 U DNA polymerase, $\mathrm{MgCl}_{2}$, deoxynucleotides), and nuclease-free water to make up a final volume of $10 \mu$ l. A T100 thermocycler (BioRad) was used, which was programmed according to the following amplification conditions: Initial denaturation 5 min at $95^{\circ} \mathrm{C}$ followed by 35 cycles of $95^{\circ} \mathrm{C}$ for $30 \mathrm{~s}, 53^{\circ} \mathrm{C}$

Table 2. Sequences used for the genus Debaryomyces and other genera to generate the dendrogram.

\begin{tabular}{lr}
\hline Species & NCBI code \\
\hline Debaryomyces hansenii & KY103235.1 \\
Debaryomyces fabryi & NR_138186.1 \\
Debaryomyces maramus & KY103271.1 \\
Debaryomyces vindobonensis & NR_138218.1 \\
Debaryomyces coudertii & NR_138161.1 \\
Debaryomyces nepalensis & NR_130651.1 \\
Debaryomyces psychrosporus & HM769277.1 \\
Debaryomyces renaii & NR_111609.1 \\
Debaryomyces castellii & NR_111306.1 \\
Debaryomyces udenii & NR_077068.1 \\
Debaryomyces prosopidis & NR_077067.1 \\
Debaryomyces vietnamensis & KY103297.1 \\
Debaryomyces udenii & KY103296.1 \\
Debaryomyces singareniensis & KY103290.1 \\
Trichophyton spp. & MH021152.1 \\
Malassezia vespertilionis & NR_157486.1 \\
Aspergillus spp. & KT221871.1 \\
Candida spp. & KX944465.1 \\
Pseudogymnoascus destructans & NR_111838.1 \\
\hline &
\end{tabular}
for $1 \mathrm{~min}, 72^{\circ} \mathrm{C}$ for $1 \mathrm{~min}$, and finally an extension of $72{ }^{\circ} \mathrm{C}$ for $10 \mathrm{~min}$. The products obtained were subjected to electrophoresis in $1 \%$ agarose gels stained with ethidium bromide (GeminiScientific, Sunnyvale, CA, USA), including a molecular weight marker of 100 pb Hyperladder (Bioline, Humber Road, London, UK).

To carry out the phylogenetic analysis of the causal agent, the amplification of a positive sample was carried out by PCR in a volume of $100 \mu \mathrm{l}$. The PCR product was verified on $1 \%$ agarose gel and gel-purified using the Wizard Genomic DNA purification kit (Promega, Madison, WI, USA) following the manufacturer's instructions. The purified product was quantified on a Nanodrop 2000 (Thermo) nanospectrophotometer and sequenced in a DNA sequencer with 16 capillary $3130 \times 1$ (Applied Biosystems, Foster City, CA, USA).

A dendrogram was generated by Sanger sequencing from the previously obtained sequence. The sequence was aligned with ITS sequences reported in the GenBank (https://www. ncbi.nlm.nih.gov/) for the genus Debaryomyces, as well as for other genera of mycotic agents reported as bat pathogens (Table 2). The construction of the dendrogram and bootstrap analysis (1000 repetitions) were performed through the bioinformatic program Mega v5.05 (Tamura et al. 2011). 
Table 1. Fungal microbiome obtained by the technique of massive sequencing (fungal diversity): The first column corresponds to the species identified for each sequence, the second column to the percentage identity in relation to the NCBI databank, the third column to the number of readings obtained through massive sequencing, the fourth column belongs to code of the NCBI sequence with which the obtanined sequence was compared and the final column corresponds to the percentage of the total readings of the massive sequencing.

\begin{tabular}{|c|c|c|c|c|}
\hline Species & Percent identity & Reads number & NCBI code & Percent reads \\
\hline Debaryomyces maramus & 98 & 17738 & KM091320.1 & 89.40524194 \\
\hline Beauveria bassiana & 100 & 364 & KY806126.1 & 1.834677419 \\
\hline Pleurotus dryinus & 99 & 342 & KY962461.1 & 1.723790323 \\
\hline Malassezia dermatis & 92 & 287 & KY104083.1 & 1.446572581 \\
\hline Leptosphaerulina chartarum & 100 & 108 & KM979510.1 & 0.544354839 \\
\hline Curvularia aeria & 98 & 84 & MF101868.1 & 0.423387097 \\
\hline Cladosporium tenuissimun & 100 & 75 & KY781763.1 & 0.378024194 \\
\hline Alternia solani & 99 & 71 & KT384228.1 & 0.357862903 \\
\hline Nigrospora sphaerica & 100 & 52 & KX688172.1 & 0.262096774 \\
\hline L042880-122 & 99 & 45 & GU053988.1 & 0.226814516 \\
\hline Cora leslactuca & 100 & 41 & KY772646.1 & 0.206653226 \\
\hline Oxyporus populinus & 99 & 36 & KJ140633.1 & 0.181451613 \\
\hline Ganoderma spp. & 99 & 35 & KF605667.1 & 0.17641129 \\
\hline Pyrigemmula aurantiaca & 89 & 35 & HM241692.1 & 0.17641129 \\
\hline Microascus hollandicus & 99 & 32 & KX923869.1 & 0.161290323 \\
\hline Hongo endofito 6303 & 100 & 32 & KR016373.1 & 0.161290323 \\
\hline Trichurus spiralis & 93 & 29 & LN850977.1 & 0.146169355 \\
\hline Phialemonium inflatum & 99 & 24 & KY305080.1 & 0.120967742 \\
\hline Camarosporula persooniae & 93 & 24 & JF770449.1 & 0.120967742 \\
\hline 109A77714 & 95 & 22 & JX389420.1 & 0.110887097 \\
\hline Paraconiothyrium brasiliense & 97 & 19 & KM100720.1 & 0.095766129 \\
\hline Phialophora intermedia & 96 & 18 & JQ766431.1 & 0.090725806 \\
\hline Acalium albonigrescens & 97 & 18 & NR146258.1 & 0.090725806 \\
\hline Microascus hyalinus & 97 & 18 & KX923871.1 & 0.090725806 \\
\hline Marasmiceae spp. & 96 & 17 & JF691144.1 & 0.085685484 \\
\hline Punctularia subhepatica & 99 & 17 & KP814559.1 & 0.085685484 \\
\hline Aspergilius jensenii & 100 & 17 & LN898704.1 & 0.085685484 \\
\hline Ganoderma australe & 99 & 16 & kU569545.1 & 0.080645161 \\
\hline 44- 2966 & 95 & 16 & FJ60971.1 & 0.080645161 \\
\hline Hypomyces aurantius & 100 & 15 & AB591044.1 & 0.075604839 \\
\hline Filobasidium chernovii & 99 & 14 & KY 514746.1 & 0.070564516 \\
\hline Cephalotrichiella penicillata & 83 & 13 & KJ869166.1 & 0.065524194 \\
\hline Microascus cirrosus & 97 & 13 & LN850782.1 & 0.065524194 \\
\hline Ilyonectria spp. & 100 & 12 & KT270187.1 & 0.060483871 \\
\hline Penicilium citreosulfuratum & 98 & 11 & KY786079.1 & 0.055443548 \\
\hline Hortaea werneckii & 100 & 11 & KU882134.1 & 0.055443548 \\
\hline Colletotrichum gloesporioides & 93 & 9 & JX669447.1 & 0.045362903 \\
\hline Microascus senegalensis & 98 & 9 & KX923932.1 & 0.045362903 \\
\hline Wallemia muriae & 97 & 9 & KX911860.1 & 0.045362903 \\
\hline Coprinopsis narcotica & 91 & 8 & FM163180.1 & 0.040322581 \\
\hline Neogymnmyces demonbreunii & 97 & 8 & JN038187.1 & 0.040322581 \\
\hline Phlebiopsis spp. & 84 & 7 & KJ832027.1 & 0.035282258 \\
\hline Coprinellus radians & 97 & 6 & KU761146.1 & 0.030241935 \\
\hline Rhodontura bacarum & 99 & 6 & KY104725.1 & 0.030241935 \\
\hline Steccherinum spp. & 96 & 5 & KM279619.1 & 0.025201613 \\
\hline Hyphodontia apacheriensis & 98 & 5 & KX857797.1 & 0.025201613 \\
\hline Passalora pseudotithoniae & 100 & 4 & NR137608.1 & 0.02016129 \\
\hline Penicilium angulare & 98 & 4 & NR121272.1 & 0.02016129 \\
\hline Aspergillus caninus & 97 & 4 & LC230093.1 & 0.02016129 \\
\hline Chaetosphaeria myriocarpa & 94 & 4 & JF340253.1 & 0.02016129 \\
\hline Cladophialophora chaetospira & 93 & 3 & EU137333.1 & 0.015120968 \\
\hline Oidiodendron spp. & 94 & 3 & JX270625.1 & 0.015120968 \\
\hline Exophiala angulospora & 86 & 3 & KR909169.1 & 0.015120968 \\
\hline Didymosphaeria spp. & 92 & 2 & KX965731.1 & 0.010080645 \\
\hline OTU F324 & 89 & 2 & MF976438.1 & 0.010080645 \\
\hline Phialocephala dimorphospora & 99 & 2 & KX881592.1 & 0.010080645 \\
\hline Steccherinum albofibrillosum & 95 & 2 & KP401770.1 & 0.010080645 \\
\hline Chaetosphaeria spp. & 100 & 2 & AY618225.1 & 0.010080645 \\
\hline Hymenochaete spp. & 100 & 2 & KU975490.1 & 0.010080645 \\
\hline Chaetomium globosum & 96 & 2 & MF682409.1 & 0.010080645 \\
\hline Exophiala halophilia & 100 & 1 & NR111628.1 & 0.005040323 \\
\hline
\end{tabular}




\section{Results}

The first bat of the M. velifer species we collected had ulcerative lesions of a round and irregular shape in the dactylo-, plagio-, and uropatagium (Plate III, Fig. 1). The specimen was fluorescence-negative; on microscopic examination, the stratum corneum was thickened by parallel sheets of anucleated keratin (hyperkeratosis). Within some hair follicles, oval amphophilic hyphae of 6-9 $\mathrm{nm}$ in diameter were observed (Plate III, Fig. 2).

The group of 12 bats were PCR-positive for the Debaryomyces genus. Histopathological analysis of all bats in the second group revealed severe lesions, such as periadnexal pyogranulomatous dermatitis, the presence of intralesional conidia and hyperkeratosis, orthokeratosis with the presence of hyphae in the form of clusters (Plate III, Fig. 2). Nine specimens presented an inflammatory infiltrate composed of lymphocytes and plasma cells below the dermis and around the cutaneous annexes. For some fungal pathogens, the normal reaction of a healthy individual to their colonization may be mediated by lymphocytes and cytokines (Romani 2004).

The phylogenetic analysis revealed that the sequence obtained from the amplification with the primers DEB-18S-RW and DEB-18S-RW was grouped in a cluster with the ITS sequences of Debaryomyces reported in the GenBank, clearly separating it from the rest of the genera of pathogenic fungi that affect bats. In addition, the sequence obtained shared $100 \%$ identity with $D$. castelli, D. prosopidis, D. renaii, D. psychrosporus, $D$. vindobonensis, D. maramus, D. fabryi, D. hansenii and D. courdetii (Plate IV, Fig. 3). The sequence with the highest number of readings (17738) showed a $100 \%$ similarity with the ITS region of Debaryomyces spp. (KM091320.1).

\section{Discussion}

The genus Debaryomyces is characterized by presence in a great variety of soils; some species of this genus have already been identified as human pathogens. Debaryomyces hansenii has been the most studied of these, being related to the contamination of intravenous catheters (Desnos-Oliver et al. 2008), causing bone infections. Debaryomyces kloeckeri has been isolated in abscesses and in urinary and dermatological infections, and finally $D$. emphysematosis has been isolated from patients with bronchitis (Wong et al. 1982).

The lesions observed in specimens such as periadnexal pyogranulomatous dermatitis, orthokeratosis hyperkeratosis, the presence of conidia and of an inflammatory infiltrate and plasma cells in the cutaneous adnexa can have a severe impact on the mobility of bats. Therefore, these lesions should be considered in the differential diagnosis of bat skin diseases such as white-nose syndrome. Debaryomyces spp. had been reported in only one other individual of M. velifer in Texas, United States (Lorch et al. 2015), and this is the first time that its presence in bats in a neotropical region has been recorded.

The implications of these findings can be severe for the conservation of Mexican bats. Though there are no demographic studies on the site, the concern is that other bats species could become infected by sharing shelters with sick individuals. To which is added the mobility and migration that different bat species can have, allowing the fungus to disperse. Although massive deaths due to fungal infections have not been reported in Mexico, the lesions shown on the wing membranes could have a severe impact on the mobility, hydration, thermoregulation and gas exchange of affected individuals. Debaryomyces spp. have not been evaluated at the level of epidemiological behaviour, so it is necessary to evaluate the populations infected with this pathogen to document the impact it may have on neotropical bat populations. 


\section{Conflict of Interest}

The authors declare that there are no conflicts of interest.

\section{Acknowledgements}

The authors thank the Consejo Nacional de Ciencia y Tecnología (CONACYT) México. This work was supported by the Secretaría de Investigación y Posgrado at the Instituto Politécnico Nacional (SIP: 20180158). Furthermore, M. B-S thanks the Comisión de Operación y Fomento a las Actividades Académicas (COFAA) and the Programa de Estímulos al Desempeño a la Investigación (EDI) at the Instituto Politécnico Nacional for their support, as well as the Sistema Nacional de Investigadores (SNI) for its recognition and support.

\section{References}

Barnard SM 2009: Bats in captivity. Volume 1. Biological and Medical Aspects. Logos Press, E.U.A. 600 p.

Blehert DS, Hicks AC, Behr M, Meteyer CU, Berlowski-Zier BM, Buckles EL, Stone WB 2009: Bat white-nose syndrome: an emerging fungal pathogen? Science 323: 227-227

Cryan PM, Meteyer CU, Boyles JG, Blehert DS 2010: Wing pathology of white-nose syndrome in bats suggests life-threatening disruption of physiology. BMC Biol 8: 1-8

Desnos-Ollivier M, Ragon M, Robert V, Raoux D, Gantier JC, Dromer F 2008: Debaryomyces hansenii (Candida famata), a rare human fungal pathogen often misidentified as Pichia guilliermondii (Candida guilliermondii). J Clin Microbiol 46: 3237-3242

Lorch JM, Minnis AM, Meteyer CU, Redell JA, Paul J, Kaarakka HM, Muller LK, Lindner DL, Verant ML, Blehert DS 2015: The fungus Trichophyton redellii sp. nov. causes skin infections that resemble white-nose syndrome of hibernating bats. J Wildl Dis 51: 36-47

Ramírez-Pulido J, González-Ruiz N, Gardner AL, Arroyo-Cabrales J 2014: List of recent land mammals from Mexico. Texas Tech University Natural Science Research Laboratory Special publications, Texas, 76 p.

Reichard JD, Kunz TH 2009: White-nose syndrome inflicts lasting injuries to the wings of little brown myotis (Myotis lucifugus). Acta Chirop 11: 457-464

Romani L 2004. Immunity to fungal infections. Nat Rev Immunol 4: 1-23

Tamura K, Peterson D, Peterson N, Stecher G, Nei M, Kumar S 2011: MEGA5: molecular evolutionary genetics analysis using maximum likelihood, evolutionary distance, and maximum parsimony methods. Mol Biol and Evol 28: 2731-2739

Turner GG, Meteyer CU, Barton H, Gumbs JF, Reeder DM, Overton B, Bandouchova H, Bartonička T, Martínková N, Pikula J, Zukal J, Blehert DS 2014: Non-lethal screening of bat wing skin using UV fluorescence to detect lesions indicating white-nose syndrome. J Wildl Dis 50: 566-573

Wong B, KiehnTE, Edwards F, Bernard EM, Marcove RC, De Harven E, Armstrong D 1982: Bone infection caused by Debaryomyces hansenii in a normal host: a case report. J Clin Microb 16: 545-548

Young JM, Weyrich LS, Cooper A 2014: Forensic soil DNA analysis using high-throughput sequencing: A comparison of four molecular markers. Foren Sci Intern Genetics 13: 176-184 


\section{Plate III}

Tamayo H. et al.: First ... pp. 301-305

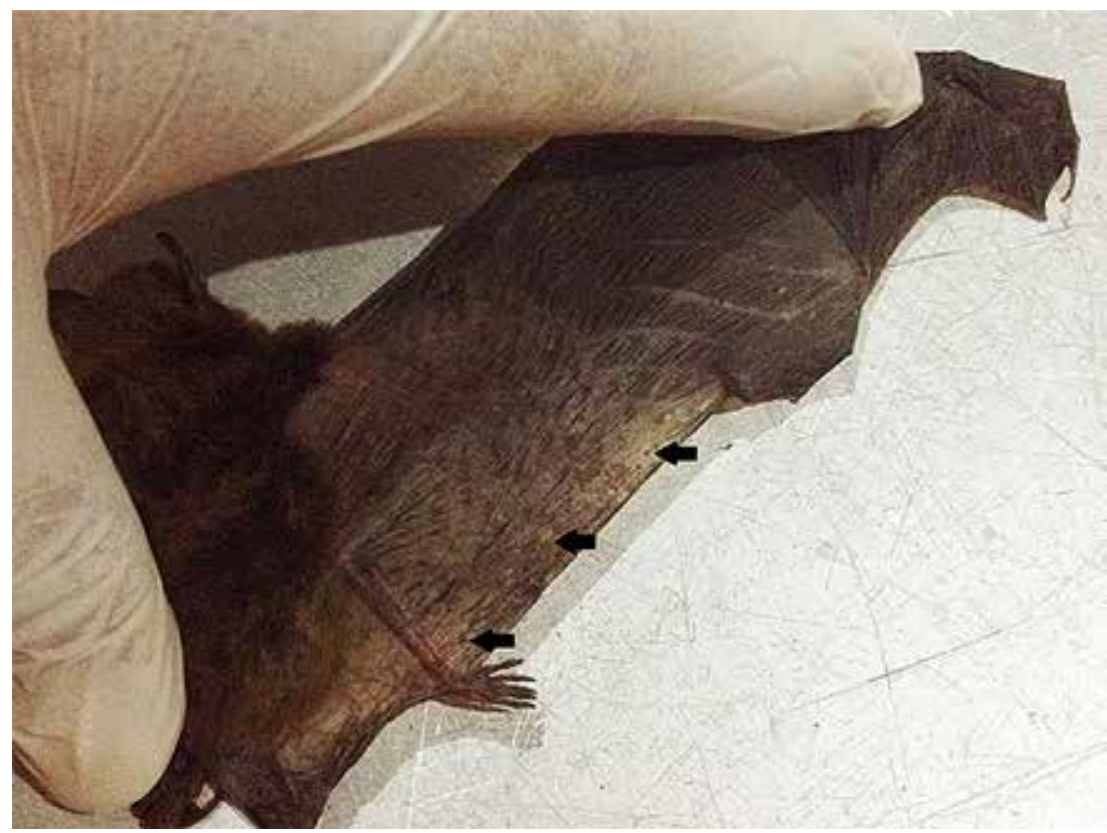

Fig. 1. Myotis velifer with ulcerative lesions, some of round shape and others of irregular form in dactylo-, plagioand uropatagium.

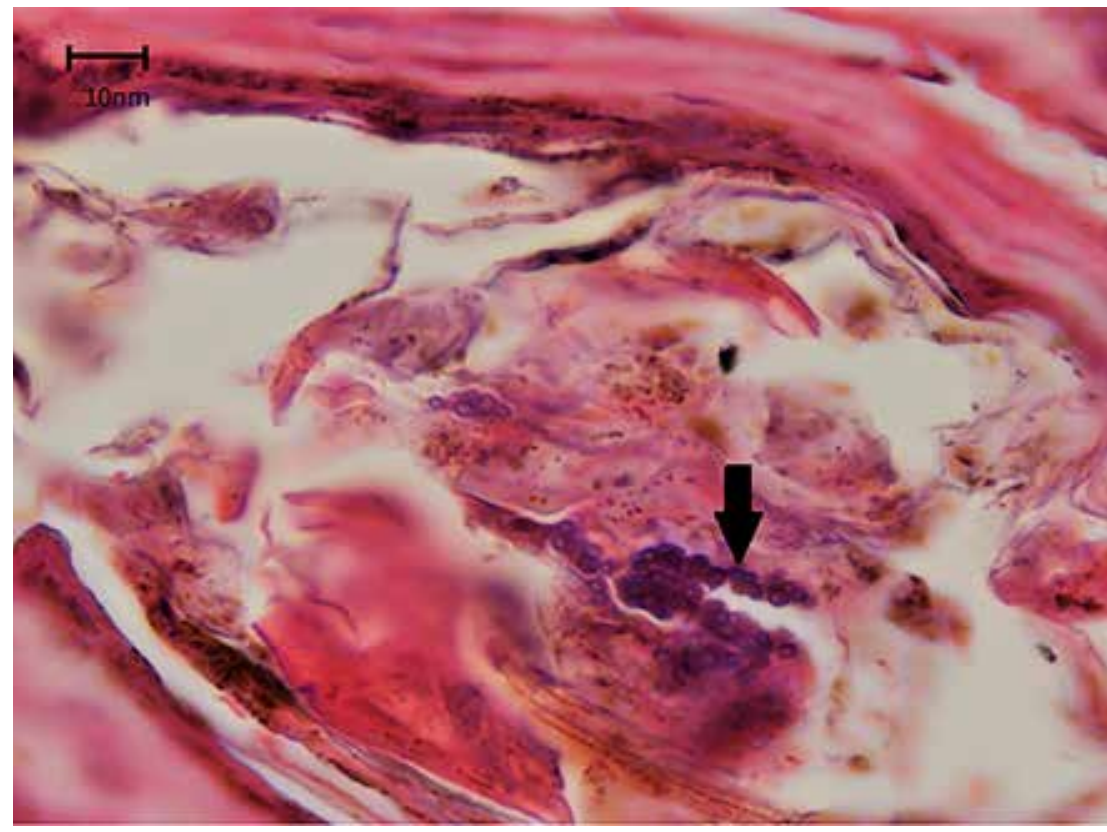

Fig. 2. The increased thickness of stratum corneum contains parallel sheets of anucleated keratin (hyperkeratosis); the presence of oval amphiphilic hyphae measuring 6-9 $\mathrm{nm}$ is observed within some hair follicles. 
Plate IV

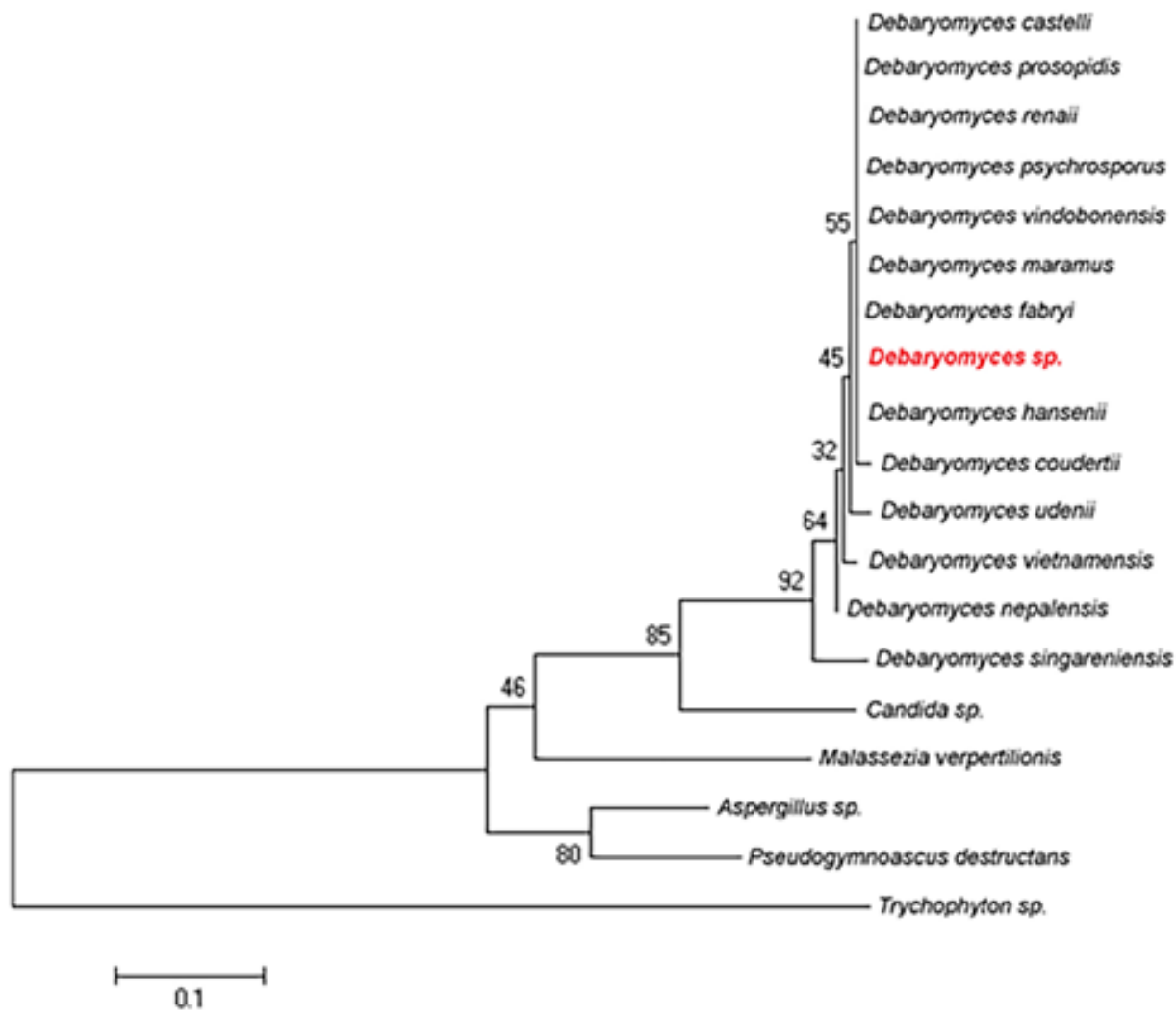

Fig. 3. Phylogenetic analysis: the referred sequence is compared to ITS databank sequences of the genus Debaryomyces and the mycotic agents reported in bats; the sequence is grouped in a clade with nine species of the genus Debaryomyces. 